\title{
Characteristics of work-related COVID-19 in Croatian healthcare workers: a preliminary report
}

\author{
Roko Žaja ${ }^{1}$, Ivana Kerner ${ }^{2}$, Jelena Macan ${ }^{3}$, and Milan Milošević ${ }^{1}$ \\ ${ }^{1}$ University of Zagreb School of Medicine, Andrija Štampar School of Public Health, Zagreb, Croatia \\ 2 Ivana Kerner, Bonifarm zdravlje, Zagreb, Croatia \\ ${ }^{3}$ Institute for Medical Research and Occupational Health, Zagreb, Croatia
}

[Received in January 2021; Similarity Check in January 2021; Accepted in March 2021]

Healthcare workers (HCWs) are considered to run a higher occupational risk of becoming infected with severe acute respiratory syndrome coronavirus 2 (SARS-CoV-2), and develop coronavirus disease (COVID-19) than the rest of the population. The aim of this study was to describe and analyse the characteristics of work-related COVID-19 in Croatian HCWs. Study participants were HCWs who contacted their occupational physician between 1 May 2020 and 12 November 2020 with a request for the registration of COVID-19 as an occupational disease. All participants filled out our online Occupational COVID-19 in Healthcare Workers Questionnaire. The study included 59 HCWs (median age 45.0, interquartile range 36.0-56.0 years). Most (78 \%) were nurses or laboratory technicians, and almost all (94.9\%) worked in hospitals. Hierarchical cluster analysis revealed three clusters of COVID-19-related symptoms: 1) elevated body temperature with general weakness and fatigue, 2) diarrhoea, and 3) headache, muscle and joint pain, anosmia, ageusia, and respiratory symptoms (nasal symptoms, burning throat, cough, dyspnoea, tachypnoea). Almost half $(44.6 \%)$ reported comorbidities. Only those with chronic pulmonary conditions were more often hospitalised than those without respiratory disorders (57.1 \% vs. $2.5 \%$, respectively; $\mathrm{P}=0.001)$. Our findings suggest that work-related COVID-19 among Croatian HCWs is most common in hospital nurses/laboratory technicians and takes a mild form, with symptoms clustering around three clinical phenotypes: general symptoms of acute infection, specific symptoms including neurological (anosmia, ageusia) and respiratory symptoms, and diarrhoea as a separate symptom. They also support evidence from other studies that persons with chronic pulmonary conditions are at higher risk for developing severe forms of COVID-19.

KEY WORDS: comorbidity; hospitalisation; questionnaire; SARS-CoV-2; symptom clustering

Working in healthcare during the coronavirus disease (COVID-19) pandemic, presents a great challenge in many respects and brings a high risk of infection with severe acute respiratory syndrome coronavirus 2 (SARS-CoV-2) due to direct or indirect everyday contact with infected people (patients and colleagues) (1-3). Recent literature suggests that healthcare workers (HCWs) in emergency/acute medicine departments are at an even higher risk of SARSCoV-2 infection than the rest, including those in intensive care units $(4,5)$. In addition, HCWs working in COVID-19 wards have a higher prevalence of antibodies against SARSCoV-2 than other frontline HCWs working in hospitals (6). Nurses seem to be more often infected and having COVID-19 than physicians (4).

HCWs who are suffering from common comorbidities, such as hypertension, chronic obstructive pulmonary disease, and diabetes are exposed to an even greater risk of SARS-CoV-2 infection (7). Such comorbidities are more often present in older workers, who are therefore more prone

Corresponding author: Roko Žaja, University of Zagreb School of Medicine, Andrija Štampar School of Public Health, Rockefellerova 4, 10000 Zagreb, Croatia, E-mail: zaja.roko@gmail.com to develop severe forms of COVID-19 that require hospitalisation, such as pneumonia (8).

Data about the COVID-19 in Croatian HCWs are scarce, and the aim of this preliminary study was to analyse the characteristics of work-related COVID-19 in Croatian HCWs.

\section{PARTICIPANTS AND METHODS}

This study included 59 Croatian HCWs from eight of the twenty-one Croatian counties, aged 18 to 65 years, who tested SARS-CoV-2-positive and contacted their occupational physician to have their COVID-19 registered as occupational disease between 1 May 2020 and 12 November 2020. Occupational physicians assessed workplace risk by taking patient's occupational history and suggested participation in the study if they tested SARSCoV-2 positive.

The study was approved by the Ethics Committees of Zagreb University School of Medicine and the Institute for Medical Research and Occupational Health, Zagreb. All participants signed an informed consent. 
Occupational physicians who collaborated in this study familiarised participating HCWs, who were their patients, with our online Occupational COVID-19 in Healthcare Workers Questionnaire. We compiled this questionnaire in Microsoft Forms ${ }^{\circledR}$ and sent the link to occupational physicians via e-mail. The physicians forwarded the link to their patients. The questionnaire starts with a short study description and continues with multiple choice questions about comorbidities, symptoms during the isolation (general weakness and fatigue, elevated body temperature, decreased sense of smell and taste, nasal congestion and fusion of postnasal secretion, cough and burning throat, severe respiratory symptoms, headache, muscle and joint pain, diarrhoea), and hospitalisation due to COVID-19. The participants were also asked to fill in their name, family name, age, personal identification number, gender, and employment info in a healthcare institution at the end of the questionnaire.

\section{Statistical analysis}

Beside the methods of descriptive statistics, characteristics and differences between hospitalised and non-hospitalised HCWs infected with SARS-CoV-2 were analysed with Fisher's exact test (for categorical variables) and Mann-Whitney $U$ test (for continuous variables).
Continuous data were represented as medians, while categorical data were represented as counts and percentages. Hierarchical cluster analysis (HCA) was used as the primary statistical method for COVID-19 related symptoms, which were coded as a binary variable ( $1=$ with symptoms and $0=$ without symptoms), to find relatively homogeneous clusters of symptoms based on measured characteristics among participants. HCA starts with each symptom as a separate cluster, and then combines clusters sequentially, reducing the number of clusters at each step, until only one cluster remains. We used the nearest neighbour as a clustering method to assess dissimilarities or distances between variables. The distance between two clusters is defined as the smallest distance between two cases in different clusters. As a distance measure between the clusters we used the squared Euclidean distance, as it places greater emphasis on objects that are further apart. All P values below 0.05 were considered significant. All statistics was run on IBM SPSS Statistics for Windows, version 25.0 (IBM Corp., Armonk, NY, USA).

\section{RESULTS}

The general characteristics of the study participants and the most reported comorbidities are shown in Table 1. Most

Table 1 General characteristics of study participants $(\mathrm{N}=59)$

\begin{tabular}{|c|c|c|c|}
\hline & & $\mathbf{N}$ & $\%$ \\
\hline \multirow{2}{*}{ Job } & Nurses / Lab technicians & 46 & 78.0 \\
\hline & Physicians & 13 & 22. \\
\hline \multirow{2}{*}{ Gender } & Men & 12 & 20.3 \\
\hline & Women & 47 & 79.7 \\
\hline Age (years) & Median (IQR) & \multicolumn{2}{|c|}{$45.0(36.0-56.0)$} \\
\hline \multirow{4}{*}{ Type of healthcare institution (affiliation) } & Health centre & 3 & 5.1 \\
\hline & General county hospital & 22 & 37.3 \\
\hline & Clinical hospital & 7 & 11.9 \\
\hline & Clinical hospital centre & 27 & 45.8 \\
\hline \multirow{2}{*}{ Any chronic comorbidity } & No & 31 & 55.4 \\
\hline & Yes & 25 & 44.6 \\
\hline \multirow{2}{*}{ Hypertension } & No & 43 & 72.9 \\
\hline & Yes & 16 & 27.1 \\
\hline \multirow{2}{*}{ Respiratory disease } & No & 54 & 91.5 \\
\hline & Yes & 5 & 8.5 \\
\hline \multirow{2}{*}{ Diabetes mellitus } & No & 57 & 96.6 \\
\hline & Yes & 2 & 3.4 \\
\hline \multirow{2}{*}{ Malignancy } & No & 58 & 98.3 \\
\hline & Yes & 1 & 1.7 \\
\hline \multirow{2}{*}{ Cardiovascular diseases } & No & 56 & 94.9 \\
\hline & Yes & 3 & 5.1 \\
\hline \multirow{2}{*}{ Other comorbidities* } & No & 48 & 81.4 \\
\hline & Yes & 11 & 18.6 \\
\hline
\end{tabular}

*Crohn's disease, hypothyroidism, Hashimoto's thyroiditis, Lupus erythematosus. IQR - interquartile range 
(78 \%) were nurses or laboratory technicians, and most $(94.9 \%)$ worked in hospitals.

Table 2 shows the self-reported occurrence of COVID-19 related symptoms, the most common of which were general weakness and fatigue ( $66.1 \%$ ), elevated body temperature $(57.6 \%)$, and impaired/lost sense of smell (40.7\%). The final cluster interpretation of agglomeration schedule and coefficient changes came up with three clinically significant clusters (cluster determination line between 20 and 25 squared Euclidean distance): 1) elevated body temperature with general weakness and fatigue, 2) diarrhoea, and 3) all other symptoms (Figure 1).

Valid responses about hospitalisation were given by 47 (79.6 \%) participants, only seven of whom (14.9\%) were hospitalised. Hospitalised and non-hospitalised participants did not differ significantly in the age, job, gender, type of health care institution, or total number of comorbidities. However, significantly more participants with respiratory comorbidity (asthma and chronic obstructive pulmonary disease) were hospitalised than not (four of seven hospitalised or $57.1 \%$ vs. one of forty non-hospitalised or $2.5 \%$, respectively; $\mathrm{P}=0.001$ ). Such significant difference was not found for any other comorbidity (listed in Table 1). Differences in COVID-19 related self-reported symptoms between hospitalised and non-hospitalized HCWs were not significant, except for cough, which was more prevalent among hospitalised than non-hospitalized patients (five of seven or $71.4 \%$ vs. six of forty or $15.0 \%$, respectively; $\mathrm{P}=0.015$ ).

\section{DISCUSSION}

Most of our participants reported mild symptoms and did not need hospitalisation. Considering their age (median 45 years; IQR 36-56 years), this was quite expected. MisraHebert et al. (9) reported that younger HCWs who are directly exposed to COVID-19 patients have higher odds to test positive to SARS-CoV-2 but lower odds to be hospitalised over COVID-19. The median age of HCWs in that study was 39.7 years, which is similar to ours. However, these data are not entirely comparable, since their sample was over $6000 \mathrm{HCWs}$ and we did not have full data about hospitalisations (12 participants did not answer that question)

Nearly half of our participants (44.6\%) reported chronic comorbidities, but two thirds of them reported hypertension, which was not found as a risk factor for severe symptoms leading to hospitalisation. Other comorbidities were rare. Participants with chronic pulmonary condition (chronic obstructive pulmonary disease and asthma) needed hospital treatment in significantly higher proportion than participants without such comorbidity. In line with that, our hospitalised participants reported cough significantly more often than non-hospitalised ones. These findings support evidence that persons with chronic pulmonary conditions are at a higher
Table 2 COVID-19 related self-reported symptoms among HCWs $(\mathrm{N}=59)$

\begin{tabular}{lcc}
\hline Symptoms & N & $\mathbf{\%}$ \\
\hline General weakness and fatigue & 39 & 66.1 \\
\hline Elevated body temperature & 34 & 57.6 \\
\hline Decreased sense of smell & 24 & 40.7 \\
\hline Muscle pain & 23 & 38.9 \\
\hline Nasal congestion & 21 & 35.6 \\
\hline Decreased sense of taste & 19 & 32.2 \\
\hline Diarrhoea & 18 & 30.5 \\
\hline Severe respiratory symptoms* & 18 & 30.5 \\
\hline Joint pain & 18 & 30.5 \\
\hline Fusion of postnasal secretion & 16 & 27.1 \\
\hline Cough & 11 & 18.6 \\
\hline Burning throat & 11 & 18.6 \\
\hline Headache & 8 & 13.6 \\
\hline
\end{tabular}

*severe respiratory symptoms: shortness of breath, tachypnoea, dyspnoea in rest

risk of developing severe forms of COVID-19 (10) and are important for assessing work ability in people with chronic pulmonary disorders whose workplaces involve high risk of SARS-CoV-2 infection. In such cases a temporary change of workplace should be considered, particularly if pulmonary disorder compromises the use of personal protective equipment.

We found three significant clusters of COVID-19 related symptoms in our participants. The first cluster includes weakness, fatigue, and elevated body temperature, which are common general symptoms of acute infection. The second cluster seems to be more COVID-19 specific with a combination of headache, muscle and joint pain, anosmia, ageusia, and respiratory symptoms (nasal secretion and congestion, burning throat, cough, shortness of breath, dyspnoea at rest, tachypnoea). The third cluster is diarrhoea alone, which points to a separate form of disease in line with other studies. Dixon et al. (11) found two clusters: one included ageusia, anosmia, and fever, the other cough, shortness of breath, and chest pain. Wise (12) found six clusters: flu-like with no fever, flu like with fever, gastrointestinal symptoms, and three clusters separating three levels of severe disease. Clusters obviously overlap between studies, but it is evident that gastrointestinal symptoms are either not there or make a separate cluster. We believe that these differences in the number of clusters is owed not only to the type and frequency of symptom reporting, but also to the choice of statistical methods in cluster determination. Anosmia is common among SARS$\mathrm{CoV}-2$ infected HCWs and is a strong predictor of infection (13). Anosmia and ageusia were reported by $30-40 \%$ of infected hospital workers in Milan, Italy (14), which is consistent with our findings. 


Decreased sense of smell
Decreased sense of taste
Cough
Severe respiratory symptoms ${ }^{\star}$
Nasal congestion
Muscle pain
Joint pain
Burning throat
Headache
Fusion of postnasal secretion
Diarrhoea
Elevated body temperature
General weakness and fatique

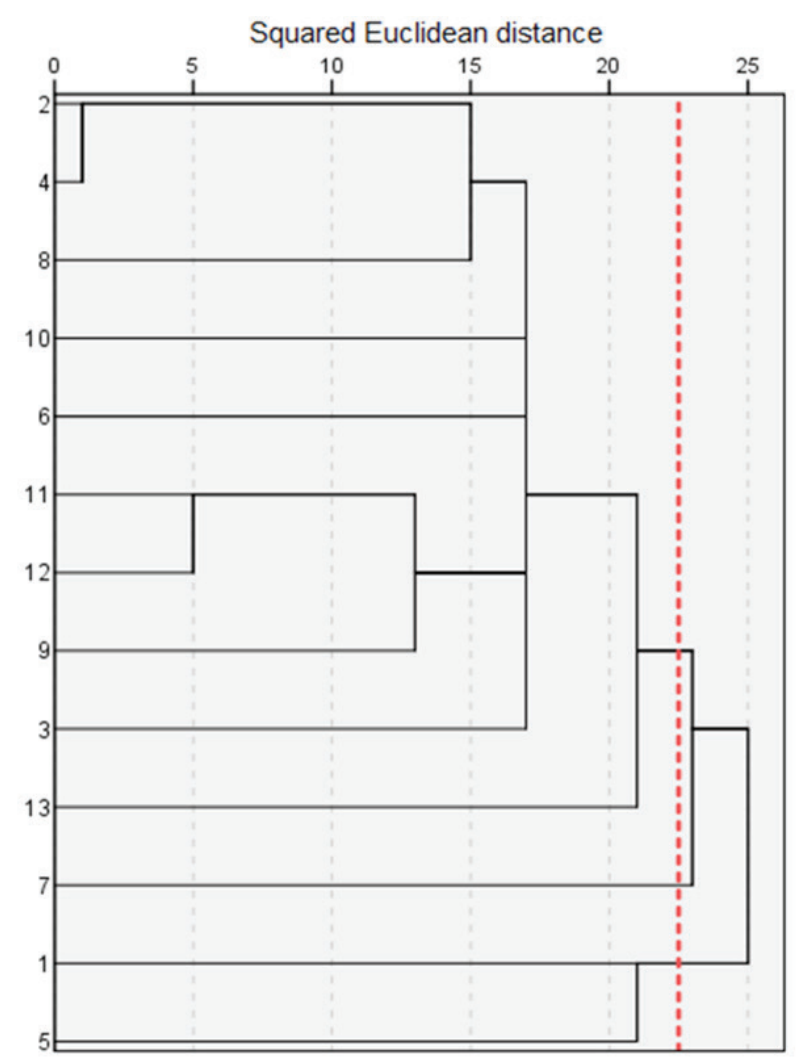

Figure 1 Clustering of symptoms reported by HCWs (N=59): blue - COVID-19 neurological, musculoskeletal, and respiratory symptoms; yellow - gastrointestinal symptom; red - acute infection symptoms. *shortness of breath, tachypnoea, dyspnoea in rest

In line with other studies (4), we noticed that significantly more hospital nurses and laboratory technicians reported COVID-19 than physicians. These findings probably suggest a higher risk of infection among nurses. Regression analysis of mortality rates by countries and professions in one study (15) revealed that nurses got more often infected with SARS-CoV-2 and ran a significantly higher risk of death than physicians in Italy, Spain, France, and Brazil.

We also noticed that of all our participants who requested that their COVID-19 is acknowledged as occupational $95 \%$ work in hospitals and only $5 \%$ in primary healthcare. This is probably because in the pandemic conditions primary care HCWs have limited their contact with patients suspect of SARS-CoV-2 infection primarily to telephone or e-mail communication.

\section{Limitations}

This study analyses preliminary data from an ongoing investigation that only includes participants claiming the acknowledgement of occupational disease. It is also limited to self-reported information and has no access to medical documentation. We had no exact information on the availability of personal protective equipment and the behaviour of HCWs in hospitals, which could explain the observed difference in infection between nurses and other HCWs.

\section{CONCLUSION}

Work-related COVID-19 among Croatian HCWs is most common in hospital nurses/laboratory technicians and takes a mild form with no need for hospital treatment. Our findings support evidence that persons with chronic pulmonary conditions are at a higher risk of developing severe forms of COVID-19. Symptom clustering points to three different clinical phenotypes: general symptoms of acute infection, COVID-19 specific neurological (anosmia, ageusia) and respiratory symptoms, and diarrhoea as a separate symptom. Further cluster analysis will involve a larger sample in order to investigate differences in symptoms between hospitalised and non-hospitalised HCWs.

\section{Acknowledgements}

The authors are pleased to acknowledge participation of occupational physicians Almenka Balenović, Helena Blažić, Dražen Bučan, Sonja Čulibrk, Edisa Ercegović, Željko Lisac, Krunoslav Mikolašević, Mate Mustać, Andrea Santini, Karolina Šimić Marinović, Goranka Škeva, Mira Vukšić, who recruited HCWs in the study. 


\section{REFERENCES}

1. Mohapatra RK, Pintilie L, Kandi V, Sarangi AK, Das D, Sahu $\mathrm{R}$, Perekhoda $\mathrm{L}$. The recent challenges of highly contagious COVID-19, causing respiratory infections: Symptoms, diagnosis, transmission, possible vaccines, animal models, and immunotherapy. Chem Biol Drug Des 2020;96:1187208. doi: $10.1111 /$ cbdd. 13761

2. de Wilton A, Kilich E, Chaudhry Z, Bell LC, Gahir J, Cadman J, Lever RA, Logan SA; UCLH COVID-19 Response Team. Delayed healthcare seeking and prolonged illness in healthcare workers during the COVID-19 pandemic: a singlecentre observational study. BMJ Open 2020;10(11):e040216. doi: 10.1136/bmjopen-2020-040216

3. Rudberg AS, Havervall S, Manberg A, Jernbom Falk A, Aguilera K, Ng H, Gabrielsson L, Salomonsson A-C, Hanke L, Murrell B, McInerney G, Olofsson J, Andersson E, Hellström C, Bayati S, Bergström S, Pin E, Sjöberg R, Tegel H, Hedhammar M, Phillipson M, Nilsson P, Hober S, Thålin C. SARS-CoV-2 exposure, symptoms and seroprevalence in healthcare workers in Sweden. Nat Commun 2020;11(1):5064 doi: 10.1038/s41467-020-18848-0

4. Martin CA, Patel P, Goss C, Jenkins DR, Price A, Barton L, Gupta P, Zaccardi F, Jerina H, Duraisingham S, Brunskill NJ, Khunti K, Pareek M. Demographic and occupational determinants of anti-SARS-CoV-2 IgG seropositivity in hospital staff. J Public Health (Oxford) 2020:1-12. doi: 10.1093/pubmed/fdaa199

5. Shields A, Faustini SE, Perez-Toledo M, Jossi S, Aldera E, Allen JD, Al-Taei S, Backhouse C, Bosworth A, Dunbar LA, Ebanks D, Emmanuel B, Garvey M, Gray J, Kidd IM, McGinnell G, McLoughlin DE, Morley G, O’Neill J, Papakonstantinou D, Pickles O, Poxon C, Richter M, Walker EM, Wanigasooriya K, Watanabe Y, Whalley C, Zielinska $\mathrm{AE}$, Crispin M, Wraith DC, Beggs AD, Cunningham AF, Drayson MT, Richter AG. SARS-CoV-2 seroprevalence and asymptomatic viral carriage in healthcare workers: a crosssectional study. Thorax 2020;75:1089-94. doi: 10.1136/ thoraxjnl-2020-215414

6. Iversen $\mathrm{K}$, Bundgaard H, Hasselbalch RB, Kristensen JH, Nielsen PB, Pries-Heje M, Knudsen AD, Christensen CE, Fogh K, Norsk JB, Andersen O, Fischer TK, Jensen CAJ, Larsen M, Torp-Pedersen C, Rungby J, Ditlev SB, Hageman I, Møgelvang R, Hother CE, Gybel-Brask M, Sørensen E, Harritshøj L, Folke F, Sten C, Benfield T, Nielsen SD, Ullum H. Risk of COVID-19 in health-care workers in Denmark: an observational cohort study. Lancet Infect Dis 2020;20:1401-8. doi: 10.1016/S1473-3099(20)30589-2

7. Ejaz H, Alsrhani A, Zafar A, Javed H, Junaid K, Abdalla AE, Abosalif KOA, Ahmed Z, Younas S. COVID-19 and comorbidities: Deleterious impact on infected patients. J Infect Public Health 2020;13:1833-9. doi: 10.1016/j. jiph.2020.07.014

8. Sanyaolu A, Okorie C, Marinkovic A, Patidar R, Younis K, Desai P, Hosein Z, Padda I, Mangat J, Altaf M. Comorbidity and its impact on patients with COVID-19. SN Compr Clin Med 2020:1-8. doi: 10.1007/s42399-020-00363-4

9. Misra-Hebert AD, Jehi L, Ji X, Nowacki AS, Gordon S, Terpeluk P, Chung MK, Mehra R, Dell KM, Pennell N, Hamilton A, Milinovich A, Kattan MW, Young JB. Impact of the COVID-19 pandemic on healthcare workers' risk of infection and outcomes in a large, integrated health system. J Gen Intern Med 2020;35:3293-301. doi: 10.1007/s11606020-06171-9

10. Cakir Edis E. Chronic pulmonary diseases and COVID-19. Turk Thorac J 2020;21:345-9. doi: 10.5152/ TurkThoracJ.2020.20091

11. Dixon BE, Wools-Kaloustian K, Fadel WF, Duszynski TJ, Yiannoutsos C, Halverson PK, Menachemi N. Symptoms and symptom clusters associated with SARS-CoV-2 infection in community-based populations: Results from a statewide epidemiological study. medRxiv 2020;2020.10.11.20210922. doi: 10.1101/2020.10.11.20210922

12. Wise J. Covid-19: Study reveals six clusters of symptoms that could be used as a clinical prediction tool. BMJ 2020;370:m2911. doi: 10.1136/bmj.m2911

13. Lan FY, Filler R, Mathew S, Buley J, Iliaki E, Bruno-Murtha LA, Osgood R, Christophi CA, Fernandez-Montero A, Kales SN. COVID-19 symptoms predictive of healthcare workers' SARS-CoV-2 PCR results. PLoS One 2020;15(6):e0235460. doi: 10.1371/journal.pone. 0235460

14. Mandic-Rajcevic S, Masci F, Crespi E, Franchetti S, Longo A, Bollina I, Velocci S, Amorosi A, Baldelli R, Boselli L, Negroni L, Zà A, Orfeo NV, Ortisi G, Centanni S, Colosio C. Source and symptoms of COVID-19 among hospital workers in Milan. Occup Med (Lond) 2020;70:672-9. doi: 10.1093/occmed/kqaa201

15. Jackson D, Anders R, Padula WV, Daly J, Davidson PM. Vulnerability of nurse and physicians with COVID-19: Monitoring and surveillance needed. J Clin Nurs 2020;29:3584-7. doi: 10.1111/jocn.15347 


\section{Karakteristike COVIDA-19 vezanog uz rad hrvatskih zdravstvenih djelatnika - preliminarna studija}

Smatra se da zdravstveni radnici imaju povećan rizik od infekcije koronavirusom teškog akutnog respiratornog sindroma 2 i od koronavirusne bolesti (COVID-19) na radnom mjestu u odnosu na ostatak populacije. Cilj je ove studije opisati i analizirati karakteristike COVIDA-19 vezanog uz rad hrvatskih zdravstvenih radnika. Ispitanici su zdravstveni radnici koji su kontaktirali nadležnog specijalista medicine rada od 1. svibnja do 12. studenoga 2020. sa zahtjevom da im se COVID-19 registrira kao profesionalna bolest. Svi ispitanici ispunili su virtualni obrazac upitnika "Profesionalna bolest COVID-19 u zdravstvenih radnika", koji su osmislili autori studije. U studiju je uključeno 59 zdravstvenih radnika (medijan dobi 45,0; interkvartilni raspon 36,0-56,0 godina). Većinu ispitanika činile su medicinske sestre/tehničari (78 \%), a gotovo svi su radili u bolnicama (94,9\%). Hijerarhijskom klasterskom analizom razdvojena su tri klastera simptoma koronavirusne bolesti: 1) vrućica, opća slabost i umor, 2) proljev i 3) glavobolja, bolovi u mišićima i zglobovima, anosmija, ageuzija, dišni simptomi (nazalni simptomi, žarenje grla, kašalj, dispneja, tahipneja). Gotovo polovina ispitanika (44,6 \%) prijavila je komorbiditete. Samo oni s kroničnim plućnim poremećajima bili su češće hospitalizirani od ispitanika bez plućnih poremećaja $(57,1 \%$ vs. $2,5 \% ; \mathrm{P}=0,001)$. Zaključno, COVID-19 vezan uz rad u hrvatskih zdravstvenih radnika najčešće se prezentira u bolničkih medicinskih sestara/tehničara kao blagi oblik bolesti. Rezultati potvrđuju tvrdnje da osobe s kroničnim plućnim poremećajima imaju veći rizik od težih oblika COVIDA-19. Klasterska analiza simptoma upućuje na tri klinička fenotipa koronavirusne bolesti: opće simptome akutne infekcije, specifične simptome koji uključuju anosmiju, ageuziju i dišne simptome te gastrointestinalni oblik bolesti.

KLJUČNE RIJEČI: hospitalizacija; klaster simptoma; komorbiditet; SARS-CoV-2; upitnik 